LUIZ Francisco Baccaro ${ }^{1}$

Vanessa de Souza Santos Machado

LÚcia Costa-Paiva'

Maria Helena Sousa ${ }^{2}$

MARIA JOSÉ OSIS ${ }^{2}$

Aarão Mendes Pinto-Neto'

\title{
Factors associated with fragility fractures in women over 50 years of age: a population-based household survey
}

\author{
Fatores associados a fraturas por fragilidade óssea em mulheres \\ acima de 50 anos de idade: um estudo de base populacional
}

Original Article

Keywords

Osteoporotic fractures/etiology

Menopause/

Risk factors

Osteoporosis/complications

Life style

Palavras-chave

Fraturas por osteoporose/etiologia

Menopausa

Fatores de risco

Osteoporose/complicações

Estilo de vida

\section{Abstract}

PURPOSE: To analyze the prevalence of and factors associated with fragility fractures in Brazilian women aged 50 years and older. METHODS: This cross-sectional population survey, conducted between May 10 and October 31, 2011, included 622 women aged $\geq 50$ years living in a city in southeastern Brazil. A questionnaire was administered to each woman by a trained interviewer. The associations between the occurrence of a fragility fracture after age 50 years and sociodemographic data, health-related habits and problems, self-perception of health and evaluation of functional capacity were determined by the $\chi^{2}$ test and Poisson regression using the backward selection criteria. RESULTS: The mean age of the 622 women was 64.1 years. The prevalence of fragility fractures was $10.8 \%$, with $1.8 \%$ reporting hip fracture. In the final statistical model, a longer time since menopause (PR 1.03; $95 \% \mathrm{Cl} 1.01-1.05 ; \mathrm{p}<0.01$ ) and osteoporosis (PR 1.97; 95\% Cl 1.27-3.08; $p<0.01$ ) were associated with a higher prevalence of fractures. CONCLUSION: These findings may provide a better understanding of the risk factors associated with fragility fractures in Brazilian women and emphasize the importance of performing bone densitometry.

\section{Resumo}

OBJETIVO: Analisar a prevalência e os fatores associados a fraturas por fragilidade óssea em mulheres brasileiras com 50 anos ou mais. MÉTODOS: Estudo transversal com base populacional, conduzido de 10 de maio de 2011 a 31 de outubro de 2011 , que incluiu 622 mulheres com idade $\geq 50$ anos, residentes em uma cidade na região Sudeste do Brasil. Foi aplicado um questionário por entrevistadores treinados. As associações entre ocorrência de fraturas por fragilidade óssea após os 50 anos e dados sociodemográficos, hábitos e problemas de saúde, autopercepção de saúde e avaliação da capacidade funcional foram realizadas por meio do teste do $\chi^{2}$ e da regressão de Poisson com critério de seleção de variáveis backward. RESULTADOS: A idade média das 622 mulheres foi 64,1 anos. A prevalência de fraturas por fragilidade óssea foi de 10,8\%,com 1,8\% relatando fratura de quadril. No modelo estatístico final, apresentar maior tempo de menopausa (RP 1,03; IC95\% 1,01-1,05; $\mathrm{P}<0,01$ ) e osteoporose (RP 1,97; IC95\% 1,27-3,08; $\mathrm{p}<0,011$ se associaram a maior prevalência de fraturas. CONCLUSÕES: Esses dados podem ajudar a melhorar o conhecimento sobre os fatores associados a fraturas por fragilidade óssea em mulheres brasileiras e enfatizar a importância da realização da densitometria óssea.
Correspondence Luiz Francisco Baccaro Av. Alexander Fleming, 10 Cidade Universitária Zeferino Vaz Zip code: 13083-881 Campinas (SP), Brazl

Received 02/09/2013

Accepted with modifications

$11 / 11 / 2013$
Study carried out at the Department of Obstetrics and Gynecology, Faculdade de Ciências Médicas, Universidade Estadual de Campinas - Unicamp - Campinas (SP), Brazil.

'Department of Obstetrics and Gynecology, Faculdade de Ciências Médicas, Universidade Estadual de Campinas - Unicamp Campinas (SP), Brazil.

${ }^{2}$ Center for Research on Reproductive Health of Campinas - Cemicamp - Campinas (SP), Brazil.

Conflict of interests: none. 


\section{Introduction}

The aging of the Brazilian population has led to increases in the proportion of women aged $\geq 50$ years, such that this age group accounted for $21.7 \%$ of the female population in 2010. With the increase in life expectancy, it has been projected that a Brazilian woman currently aged 50 years will survive for about 31 more years ${ }^{1}$. Fragility fractures are a major health problem in the elderly, with hip fractures in particular being a problem not only for the patient, but also in terms of higher healthcare costs ${ }^{2}$. The mortality rate during the first year after a hip fracture is around $10-35 \% \%^{3}$, and it has been estimated that only about $50 \%$ of individuals who have suffered a hip fracture will be able to reestablish their daily activities ${ }^{4}$. Recent studies have estimated the prevalence of bone fragility fractures in Brazilian women at $11.5-21.3 \% \%^{5-7}$, and the annual incidence of hip fracture adjusted for age was estimated to be 199 per $100,000^{2}$.

Recently, mathematical models that combine clinical risk factors and measurements of bone mineral density (BMD) at the femoral neck have been used in several countries to estimate the risk of fragility fractures, and thus plan the therapeutic strategy for each individual ${ }^{8}$. Factors associated with a higher prevalence of fractures in Brazil include patient age, family history of hip fractures, early menopause, sedentary lifestyle, poor quality of life, high intake of phosphorus, diabetes mellitus, use of benzodiazepines, low BMD, and recurrent falls ${ }^{9}$. In addition, the FRAX ${ }^{\circledR}$ fracture assessment tool was released for use in the Brazilian population ${ }^{10}$.

Knowledge of the risk factors associated with fragility fractures is important in formulating appropriate public health spending plans in a vast country like Brazil, as well as to improve and customize types of treatment. To better understand the prevalence of, and factors associated with, bone fragility fractures in Brazilian women, we assessed these parameters in women aged $\geq 50$ years living in a city in southeastern Brazil.

\section{Methods}

This is a secondary analysis of a cross-sectional study entitled "Health conditions in women over 50 years: A population-based study in Campinas, São Paulo", conducted from May 10 to October 31, 2011 in the city of Campinas, São Paulo, Brazil. A total of 66 census sectors were selected in the city by simple random sampling or equal probabilities of selection, based on a list supplied by the Brazilian Institute of Geography and Statistics (IBGE), and classified according to the identification number of each sector. The IBGE census sectors were numbered and their geographical limits were clearly defined. The sectors were classified in accordance with the database of the 2000 census for the city of Campinas. All census sectors with at least ten women aged 50 years or older residing in them were included in the random selection process. The sectors in which there were fewer than ten women in this age group were grouped together with the consecutively numbered neighboring sector. Research assistants, guided by maps of each census area, went to odd-numbered houses and enquired whether any of the residents were women aged 50 years or older. Any woman who fulfilled the eligibility criteria was invited to participate in the study. If she agreed to participate, a questionnaire was implemented in person or by telephone by interviewers trained at the Campinas Center for Research and Control of Maternal and Child Diseases. This was repeated until 10 eligible women were obtained in each sector. If the required number of women was not achieved in a particular sector, visits to homes in that sector were reinitiated, going to those that had not been previously visited. A total of 721 women were invited to participate in the study. Ninety-nine women (13.7\%) declined to participate, principally reporting a lack of time in which to answer the questionnaire. Therefore, the final sample comprised 622 women. All women signed free and informed written consents before their interviews. The study was approved by the Research Ethics Committee of UNICAMP under the number 1012/2010.

According to IBGE, the population of Campinas in 2007 was $1,039,000$, of whom approximately 545,000 were women. Approximately 131,800 of these women were aged 50 years or older. As this was a survey on different morbidities, hypertension was taken into consideration as the most prevalent morbidity in women in Brazil, with an estimated prevalence of $56.3 \%$. A type 1 (alpha) error of $5 \%$ and a margin of error of $5 \%$ were considered. The resulting sample size was then increased by $10 \%$ to compensate for a possible loss of subjects; therefore, the final sample size was established as 657 women.

The study selected women aged 50 years or older residing in the city of Campinas, São Paulo, Brazil.

Explicit refusal to participate in the study or any factor preventing the interview from taking place, such as illness, personal commitments, or incompatibility of schedules, constituted exclusion criteria. Women with a cognitive disability that prevented them from answering the questionnaire or those suffering from dementia were also excluded.

The dependent variable was the presence of a fragility fracture at age 50 years or above. This was established using the question: "Has a doctor ever told you that you had broken a bone at age 50 years or above?", with responses "yes", "no" or "do not know". Of women answering "yes" to the question, those who reported having had only a fractured tibia/leg, foot or anklebone were excluded because fractures at these sites may not have been fragility fractures ${ }^{5}$.

The independent variables were age; education; marital status; skin color; monthly income; body mass index; 
difference between current weight and weight at 20-30 years of age; smoking; if a past or current smoker, the number of cigarettes/day; alcohol consumption; frequency of alcohol consumption; weekly physical exercise; frequency of physical exercise; having to stay in bed for more than half a day during the preceding 2 weeks due to illness or pain; number of days spent in bed during the previous 2 weeks; hospitalization during the previous year; number of months since the last medical consultation; treatment with any drugs acting on the central nervous system (CNS), medications used to treat menopausal symptoms, anti-rheumatic drugs, medications to treat osteoporosis, antihypertensive drugs, antilipidemic agents, antidiabetic drugs, cardiac drugs, thyroid hormones, anti-ulcer drugs, and analgesics; and use of alternative treatments. Other factors included having private medical insurance; stopping menstruation more than one year earlier; time since menopause in years; menopausal treatment, including hormonal treatment and treatment with natural menopausal remedies; duration of menopausal treatment in months; problems maintaining balance while walking, taking a bath, dressing, or going down stairs; falls within the previous 12 months; fear of falling; whether this fear interfered with routine activities; self-perception of health; and difficulties in feeding, taking a bath, going to the toilet, running, lifting heavy items, participating in sports or heavy work, pushing a table or doing housework, climbing stairs, crouching or kneeling, walking $100 \mathrm{~m}$ and walking more than $1 \mathrm{~km}$.

Other independent variables included a diagnosis of diabetes, time since diagnosis of diabetes, and receipt of treatment for diabetes; diagnosis of cancer, time since diagnosis, and receipt of treatment for cancer; diagnosis of osteoarthritis and time since diagnosis; diagnosis of hypertension and time since diagnosis; use of antihypertensive medication; previous heart attack; previous stroke, time since diagnosis, and sequelae due to stroke; diagnosis of bronchitis, asthma, or emphysema; diagnosis of osteoporosis or bone weakness, time since diagnosis, and receipt of treatment for osteoporosis; diagnosis of glaucoma or cataract and time since diagnosis of cataract; wearing of glasses or contact lenses and ability to see well; use of a hearing aid(s) and ability to hear well; urinary incontinence; active sex life; and number of comorbidities.

The questionnaire used in the present study was based on three preexisting questionnaires: two developed in Brazil ${ }^{11,12}$ and another in the USA ${ }^{13}$. It was structured in five sections related to the data of interest to the study: a sociodemographic evaluation, health-related habits, self-perception of health, evaluation of functional capacity, and health-related problems. The variables were based on the women's self-reported responses.

Initially, a simple descriptive analysis of the cases of fragility fractures was performed using a frequency distribution.
Women who reported exclusively fracture of the tibia/leg, foot or anklebones were then excluded from the analysis. Next, a bivariate analysis using the $\chi^{2}$ test ${ }^{14}$ was performed to assess the association between the dependent variable and the independent variables. Finally, a Poisson multiple regression model was constructed ${ }^{15}$, with the prevalence ratios (PRs) and respective $95 \%$ confidence intervals $(95 \% \mathrm{CI}$ ) calculated to identify significant independent variables using backward selection. The significance level was established at 5\% and the cluster sampling (census sector) was used in the bivariate and multiple analyses. The analyses were performed using SPSS $^{\circledR}$, version 20.0 (IBM Corp., Armonk, NY, USA) and STATA ${ }^{\circledR}$ version 7 (StataCorp LP, TX, USA).

\section{Results}

A total of 622 women aged 50 years or older answered the questionnaire. The mean age was 64.1 years, $70.4 \%$ had at least 8 years of education, $52.2 \%$ were not living with a partner, $70.4 \%$ were white, $53.6 \%$ reported a monthly family income of $\mathrm{R} \$ 1.500$ or less, $37.9 \% \mathrm{had}$ a BMI between 25 and 29.99, 36.3\% were smokers or had previously smoked, $15.0 \%$ drank alcohol regularly, $36.2 \%$ practiced physical exercise on a weekly basis, and $21.3 \%$ reported being affected by osteoporosis.

After exclusion of women with fractures exclusively in the foot or ankle or missing data $(n=18)$, the prevalence of fragility fractures at age 50 or over in the study population was $10.8 \%(\mathrm{n}=65)$, with $1.8 \%$ reporting hip fracture $(\mathrm{n}=11)$ (Table 1$)$. In the bivariate analysis, an association was observed between fragility fractures and age $(\mathrm{p}<0.01)$, white race $(\mathrm{p}=0.04)$, weight loss compared with weight at $20-30$ years $(\mathrm{p}=0.02)$, not doing physical exercise weekly $(\mathrm{p}=0.04)$, a longer time since the menopause $(\mathrm{p}<0.01)$, fear of falling $(\mathrm{p}=0.02)$, fear of falling

Table 1. Prevalence and distribution of fractures in women aged $\geq 50$ years

\begin{tabular}{lcc}
\hline & n & $\%$ \\
\hline $\begin{array}{l}\text { Fracture * } \\
\text { Yes }\end{array}$ & 65 & 10.8 \\
No & 537 & 89.2 \\
$\quad$ Total & 602 & 100.0 \\
Fractured bone \# & 11 & 1.8 \\
$\quad$ Femur/Hip & 10 & 1.7 \\
Wrist & 50 & 8.3 \\
Other & 1 & 0.2 \\
Tibia/Leg (not exclusive) & 6 & 1.0 \\
Foot (not exclusive) & 1 & 0.2 \\
Ankle (not exclusive) & & \\
\hline * 18 women with fractures exclusively in the foot or ankle were excluded; one \\
woman who did not answer the question about medical diagnosis and one woman \\
who could not tell which bone was broken were excluded. \\
\#Includes women with a broken bone in more than one site.
\end{tabular}


that affected their daily activities $(\mathrm{p}<0.01)$, reporting osteoporosis ( $\mathrm{p}<0.01)$, multimorbidity $(\mathrm{p}=0.02)$, and not being sexually active $(\mathrm{p}<0.01)$ (Table 2$)$. Regarding the variables in self-assessment of functional capacity, there was an association between fragility fractures and having difficulty pushing a table or doing housework $(\mathrm{p}<0.01)$, being unable to climb stairs $(\mathrm{p}<0.01)$, and being unable to crouch or kneel down $(\mathrm{p}<0.01)$ (Table 3$)$.

Table 2. Factors associated with occurrence of fractures $(n=602)$

\begin{tabular}{|c|c|c|c|c|}
\hline \multirow{2}{*}{ Variable } & \multicolumn{2}{|c|}{ Fracłure (\%) } & \multirow{2}{*}{ n } & \multirow{2}{*}{ p-value* } \\
\hline & Yes & No & & \\
\hline Age (years) & & & & $<0.01$ \\
\hline $50-59$ & 4.6 & 95.4 & 239 & \\
\hline $60-69$ & 13.6 & 86.4 & 191 & \\
\hline$\geq 70$ & 16.3 & 83.7 & 172 & \\
\hline Skin color & & & & 0.04 \\
\hline White & 12.5 & 87.5 & 415 & \\
\hline Non-white & 7.3 & 92.7 & 179 & \\
\hline $\begin{array}{l}\text { Difference between the current weight and } \\
\text { the weight at } 20-30 \text { years of age (in } \mathrm{kg} \text { ) }\end{array}$ & & & & 0.02 \\
\hline$<0$ & 15.9 & 84.1 & 44 & \\
\hline $0.0-14.9$ & 6.2 & 93.8 & 194 & \\
\hline $15.0-29.9$ & 15.5 & 84.5 & 155 & \\
\hline$\geq \mathbf{3 0 . 0}$ & 6.3 & 93.7 & 63 & \\
\hline Weekly physical exercise & & & & 0.04 \\
\hline Yes & 7.3 & 92.7 & 218 & \\
\hline No & 12.8 & 87.2 & 384 & \\
\hline Time since menopause (years) & & & & $<0.01$ \\
\hline 0 & 5.3 & 94.7 & 38 & \\
\hline $1-10$ & 4.0 & 96.0 & 174 & \\
\hline $11-20$ & 11.8 & 88.2 & 178 & \\
\hline $21-30$ & 17.1 & 82.9 & 117 & \\
\hline$>30$ & 15.8 & 84.2 & 57 & \\
\hline Fear of falling & & & & 0.02 \\
\hline Yes & 13.2 & 86.8 & 357 & \\
\hline No & 7.3 & 92.7 & 245 & \\
\hline $\begin{array}{l}\text { Fear of falling interfering with routine } \\
\text { activities }\end{array}$ & & & & $<0.01$ \\
\hline Yes & 17.9 & 82.1 & 134 & \\
\hline No & 10.3 & 89.7 & 223 & \\
\hline She was not afraid & 7.3 & 92.7 & 245 & \\
\hline Osteoporosis & & & & $<0.01$ \\
\hline Yes & 19.8 & 80.2 & 126 & \\
\hline No & 8.5 & 91.5 & 468 & \\
\hline Number of comorbidities & & & & 0.02 \\
\hline 1 & 6.9 & 93.1 & 246 & \\
\hline$\geq 2$ & 13.6 & 86.4 & 338 & \\
\hline Active sexual life & & & & $<0.01$ \\
\hline Yes & 5.4 & 94.6 & 224 & \\
\hline No & 14.0 & 86.0 & 378 & \\
\hline
\end{tabular}

${ }^{*} \chi^{2}$ test using cluster sampling as the primary sampling unit.

Significant p-values are shown in bold.
Table 3. Association between the occurrence of fractures and variables of self-assessment of functional capacity $(\mathrm{n}=602)$

\begin{tabular}{|c|c|c|c|c|}
\hline \multirow{2}{*}{ Variable } & \multicolumn{2}{|c|}{ Fracture (\%) } & \multirow{2}{*}{ n } & \multirow{2}{*}{ p-valuex } \\
\hline & Yes & No & & \\
\hline Pushing a table or doing housework & & & & $<0.01$ \\
\hline Unable to & 11.1 & 88.9 & 36 & \\
\hline Had a lot of difficulty & 26.1 & 73.9 & 46 & \\
\hline Had little difficulty & 14.1 & 85.9 & 99 & \\
\hline Had no difficulty & 8.3 & 91.7 & 421 & \\
\hline Climbing stairs & & & & $<0.01$ \\
\hline Unable to & 23.5 & 76.5 & 51 & \\
\hline Had a lot of difficulty & 8.3 & 91.7 & 72 & \\
\hline Had little difficulty & 15.4 & 84.6 & 117 & \\
\hline Had no difficulty & 8.0 & 92.0 & 362 & \\
\hline Crouching or kneeling down & & & & $<0.01$ \\
\hline Unable to & 18.9 & 81.1 & 95 & \\
\hline Had a lot of difficulty & 14.6 & 85.4 & 82 & \\
\hline Had little difficulty & 10.8 & 89.2 & 148 & \\
\hline Had no difficulty & 6.9 & 93.1 & 277 & \\
\hline
\end{tabular}

In the multiple regression analysis, a higher prevalence of fragility fractures at 50 years or older was associated with a longer time since the menopause (PR 1.03; 95\% CI 1.01-1.05; $\mathrm{p}<0.01$ ) and having osteoporosis (PR $1.97 ; 95 \%$ CI 1.27-3.08; $\mathrm{p}<0.01)$.

\section{Discussion}

The aim of this study was to evaluate the prevalence of fragility fractures and their associated risk factors in women aged $\geq 50$ years in the city of Campinas, São Paulo, Brazil. The overall prevalence of bone fragility fractures was $10.8 \%$, whereas the prevalence of femoral/hip fractures was $1.8 \%$. These results are similar to those obtained in national studies, which estimated that the prevalence of fragility fractures in older women was $11.5-21.3 \%{ }^{5-7}$, and the prevalence of femoral/hip fractures was $1.26 \%{ }^{7}$.

Although BMD has been used as a predictor of fragility fractures, this parameter has yielded unclear results. Most individuals who suffer fractures do not have BMDs consistent with osteoporosis according to World Health Organization criteria. In addition, younger individuals with densitometric osteoporosis, but without other risk factors, have relatively low rates of fractures ${ }^{16}$. In recent years, efforts have been made to develop mathematical models that combine BMD and clinical risk factors to predict the risk of fragility fractures, and thus to individualize therapeutic strategies ${ }^{8}$. In Brazil, the clinical risk factors for fragility fractures have not yet been fully determined, although the Brazilian Osteoporosis Study (BRAZOS) identified advanced age, family history of hip 
fracture, early menopause, sedentary lifestyle, poor quality of life, high intake of dietary phosphorus, diabetes mellitus, use of benzodiazepines and recurrent falls during the previous year as risk factors for fragility fractures 5 . In addition, the São Paulo Osteoporosis Study (SAPOS) identified age, duration of menopause, and family history of hip fracture as risk factors for fragility fractures, and regular physical activity as a protective factor ${ }^{7}$. Recently the FRAX ${ }^{\circledR}$ fracture assessment tool was released for use in the Brazilian population; this tool can be used to calculate fracture risk and plan the most appropriate type of therapy for each patient ${ }^{10}$.

In the present study, bivariate analysis identified several factors previously associated with fragility fractures, including age, white race, lower weight than at age 20-30 years, a longer time since menopause, and osteoporosis ${ }^{17}$. Other factors identified in our bivariate analysis may be related to the aging process itself, including an inactive sexual life and multimorbidity. There was no association between falls and fracture prevalence, but there was an association between fear of falling and fracture prevalence. This finding suggests that women who have experienced a fracture are afraid of falling and of a possible new fracture, with a resultant reduction in their quality of life. A recent population-based study showed that the factors associated with falls in Brazilian women were trouble maintaining balance when walking, alcohol consumption, admission to a hospital during the previous 12 months, and cataracts. Administration of some type of treatment for menopause and having health insurance were associated with a lower prevalence of falls ${ }^{18}$.

In addition to factors intrinsic to the individual, the assessment of functional capacity has been used to predict the chances of having osteoporosis and fragility fractures. In the present study, we found an association between a higher prevalence of fractures and lack of weekly physical exercise, difficulties pushing a table or doing housework, and inability to climb stairs, crouch or kneel down. Women with impaired functional capacity have a higher risk of osteoporosis ${ }^{19}$. In addition, a prospective cohort study of postmenopausal Finnish women demonstrated that factors associated with an increased risk of bone fracture included failing to maintain balance on one foot for more than 10 seconds, grip strength, and difficulty walking 100 meters $^{20}$.

In the final statistical model, Poisson regression identified only two variables independently associated with a higher prevalence of fragility fractures: a longer time since the menopause and osteoporosis. A previous prospective longitudinal study in white women showed bone loss of $10.5 \%$ at the spine, $5.3 \%$ at the femoral neck, and $7.7 \%$ throughout the entire body during the first 5-7 years after menopause. Although these losses may have been due to the natural aging process, low serum estrogen concentrations, leading to imbalances between bone formation and resorption, were thought to be responsible for about two-thirds of bone loss ${ }^{21}$. The FRAX ${ }^{\circledast}$ tool includes hypogonadism and menopause before age 45 years as causes of secondary osteoporosis $^{8}$. In older women around 70 years of age, however, the risk of fracture was found to be independent of the time of menopause $\mathrm{e}^{22,23}$.

The lack of association between clinical risk factors and bone fragility fractures in our final statistical model suggests that bone densitometry may be of great importance in identifying Brazilian women who are more likely to suffer fractures due to bone fragility, especially those with a history of early menopause. In 2002, the Ministry of Health of Brazil ${ }^{24}$ issued a decree (n. 1101/GM) establishing the parameters for public health system support, such as the expected amount of medical equipment. Based on these parameters, $7.1 \mathrm{x}$-ray bone densitometry machines would be available for every million inhabitants ${ }^{24}$. In 2009, $\mathrm{IBGE}^{25}$ reported that the total availability, in both the private and public sectors, was 5.6 bone densitometry machines per million persons in Brazil in 2005, but was only 1.5 per million in the public health system, which corresponds to $20 \%$ of the need set out by the 2002 ministerial decree. It is noteworthy that, in the current study, $21.3 \%$ of women reported being affected by osteoporosis; of these, $77.9 \%$ underwent bone densitometry to identify the pathology. Although the latter percentage was higher than expected, this study was conducted in Campinas, São Paulo, a city located in one of the richest regions of the country, where it is easier to perform diagnostic examinations both through the public and private health systems.

This study had several limitations, especially those associated with its cross-sectional design, which has known statistical limitations. The variables were based on selfreports, and it was not possible to confirm the reported diseases and conditions by laboratory tests, X-rays and bone densitometry. However, since this is a populationbased study, we believe that these limitations did not affect the final analysis, because any errors may have resulted equally in an increase or decrease in diagnosis of the conditions investigated. Furthermore, this study is part of a large population survey on multimorbidities, and some variables, such as family history of fragility fractures, could not be obtained.

In conclusion, the prevalence of bone fragility fractures in women aged $\geq 50$ years in Campinas was similar to that reported in previous national studies. Factors associated with a higher prevalence of fractures were a longer time since menopause and osteoporosis. These findings may provide a better understanding of the risk factors associated 
with clinical fragility fractures in Brazilian women. They also emphasize the importance of performing bone densitometry, especially in women who use the public health system. This may result in earlier therapy, decreasing the incidence of fragility fractures throughout the country.

\section{Acknowledgement}

To Fundação de Amparo à Pesquisa do Estado de São Paulo (FAPESP) which have financed this study through the Process No. 2010/15867-1.

\section{References}

1. Instituto Brasileiro de Geografia e Estatística (IBGE) [Internet]. Censo 2010: resultados [citado $2013 \mathrm{Fev}$ 14]. Disponível em: <http://censo2010.ibge.gov.br/resultados>

2. Kanis JA, Odén A, McCloskey EV, Johansson H, Wahl DA, Cooper $\mathrm{C}$, et al. A systematic review of hip fracture incidence and probability of fracture worldwide. Osteoporos Int. 2012;23(9):2239-56.

3. Hughson J, Newman J, Pendleton RC. Hip fracture management for the hospital-based clinician: a review of the evidence and best practices. Hosp Pract (1995). 2011 1;39(1):52-61.

4. Auron-Gomez M, Michota F. Medical management of hip fracture. Clin Geriatr Med. 2008;24(4):701-19, ix.

5. Pinheiro MM, Ciconelli RM, Martini LA, Ferraz MB. Clinical risk factors for osteoporotic fractures in Brazilian women and men: the Brazilian Osteoporosis Study (BRAZOS). Osteoporos Int. $2009 ; 20(3): 399-408$.

6. Siqueira FV, Facchini LA, Hallal PC. The burden of fractures in Brazil: a population-based study. Bone. 2005;37(2):261-6.

7. Pinheiro MM, Reis Neto ET, Machado FS, Omura F, Yang JHK, Szejnfeld J, et al. Risk factors for osteoporotic fractures and low bone density in pre and postmenopausal women. Rev Saúde Pública. 2010;44(3):479-85

8. Kanis JA, Johnell O, Oden A, Johansson H, McCloskey E. FRAX and the assessment of fracture probability in men and women from the UK. Osteoporos Int. 2008; 19(4):385-97.

9. Pinheiro MM, Eis SR. Epidemiology of osteoporotic fractures in Brazil: what we have and what we need. Arq Bras Endocrinol Metabol. 2010;54(2):164-70.

10. FRAX: WHO Fracture Risk Assessment Tool [Internet]. Calculation tool [cited 2013 May 7]. Available from: <http://www.shef.ac.uk/ FRAX/tool.aspx? country=55>

11. Lebrão ML, Duarte YAO. SABE - Saúde, bem-estar e envelhecimento O projeto SABE no município de São Paulo: uma abordagem inicial. Brasília (DF): Organização Pan-Americana de Saúde; 2003.

12. Brasil. Ministério da Saúde. Secretaria de Vigilância em Saúde [Internet]. Vigilância de fatores de risco e proteção para doenças crônicas não transmissíveis por entrevistas telefônicas (VIGITEL). 2008 [citado $2013 \mathrm{Fev}$ 14]. Disponível em: <http://portal.saude. gov.br/portal/arquivos/pdf/167_Q2008.pdf>

13. Guralnik JM, Fried LP, Simonsick EM, Kasper JD, Lafferty ME, editors. The women's health and aging study: health and social characteristics of older women with disability. Bethesda: National Institute on Aging; 1995. (NIH Pub. No. 95-4009).
14. Altman DG. Practical statistics for medical research. Boca Raton: Chapman \& Hall/CRC; 1999.

15. Barros AJD, Hirakata VN. Alternatives for logistic regression in cross-sectional studies: an empirical comparison of models that directly estimate the prevalence ratio. BMC Med Res Methodol. 2003;3:21

16. Baim S, Leslie WD. Assessment of fracture risk. Curr Osteoporos Rep. 2012;10(1):28-41.

17. National Osteoporosis Foundation. Clinician's guide to prevention and treatment of osteoporosis. Washington, DC: National Osteoporosis Foundation; 2010.

18. Baccaro LF, Machado VSS, Costa-Paiva L, Sousa MH, Osis M, Pinto-Neto AM. Treatment for menopausal symptoms and having health insurance were associated with a lower prevalence of falls among Brazilian women. Maturitas. 2013;75(4):367-72.

19. Baccaro LF, Machado VSS, Costa-Paiva L, Souza MH, Osis M, Pinto-Neto AM. Factors associated with osteoporosis in Brazilian women: a population-based household survey. Arch Osteoporos. 2013;8(1-2):138.

20. Kärkkäinen $M$, Rikkonen $T$, Kröger $H$, Sirola J, Tuppurainen $M$, Salovaara K, et al. Association between functional capacity tests and fractures: an eight-year prospective population-based cohort study. Osteoporos Int. 2008;19(8):1203-10.

21. Recker R, Lappe J, Davies K, Heaney R. Characterization of perimenopausal bone loss: a prospective study. J Bone Miner Res. 2000; 15(10): 1965-73.

22. Ohta H, Sugimoto I, Masuda A, Komukai S, Suda Y, Makita $\mathrm{K}$, et al. Decreased bone mineral density associated with early menopause progresses for at least ten years: cross-sectional comparisons between early and normal menopausal women. Bone. 1996; 18(3):227-31.

23. Gerdhem P, Obrant KJ. Bone mineral density in old age: the influence of age at menarche and menopause. J Bone Miner Metab. 2004;22(4):372-5.

24. Brasil. Ministério da Saúde [Internet]. Portaria n $1101 / G M, 12$ junho 2002 [citado 2013 Fev 14]. Disponível em: <http://dtr2001. saude.gov.br/sas/PORTARIAS/Port2002/Gm/GM-1 101.htm>

25. Instituto Brasileiro de Geografia e Estatística (IBGE) [Internet]. Indicadores sociodemográficos e de saúde no Brasil: 2009. Rio de Janeiro: IBGE; 2009. Escassez e fartura: distribuição da oferta de equipamentos de diagnóstico por imagem no Brasil [citado 2013 Fev 14]. Disponível em: <http://www.ibge.gov.br/home/ estatistica/populacao/indic_sociosaude/2009/com_esca.pdf> 